\title{
DAMPAK DAN KENDALA WISATA WADUK SERMO DARI ASPEK LINGKUNGAN HIDUP DAN RISIKO BENCANA
}

\author{
Sudarmadji \\ Program Studi Ilmu Lingkungan Sekolah Pascasarjana Universitas Gadjah Mada \\ E-mail: sudarmadji@ugm. ac.id \\ Widyastuti \\ Jurusan Geografi Lingkungan Fakultas Geografi Universitas Gadjah Mada
}

\begin{abstract}
Sermo Reservoir is a multipurpose reservoir. With its natural beauty as, and is the only reservoir in Yogyakarta Special Region, should have been visited by many tourists. Tourism activities in the reservoir may cause environmental impact, and may have risk disaster for the tourists. This study aims to determine the potential of the Sermo Reservoir as natural tourisms object and in general to analyze environmental impacts and disaster risks caused by tourism activities. The study was conducted by field surveys, observations and interviews with local community. Reservoir water samples were collected for physical and chemical parameters analysis and evaluated by the standard requirement of water for tourism activities. Data analysis was performed using descriptive qualitative and quantitative methods, using tables and diagram of processed data. In general it was found that the Sermo Reservoir has highly potential for tourism, but due to the lack of the supporting facilities, the tourist coming to the Serwo Reservoir are still not optimal yet. The environmental impact caused by tourism activities have occurred. The positive impact that arises are the business opportunities and increased revenue of the local people, while the negative impacts are the pollution caused by solid waste and water quality degradation. The risk of dissaster may come from accidents when conducting activities in the reservoir, and it should be considered in the Sermo Reservoir for tourism development.
\end{abstract}

Keywords: Sermo Reservoir, tourism, environmental impact, disaster risk, development.

\begin{abstract}
ABSTRAK
Waduk Sermo merupakan waduk multiguna. Dengan keindahan alamnya dan merupakan satu-satunya waduk di Daerah Istimewa Yogyakarta, mestinya banyak dikunjungi oleh wisatawan. Kegiatan wisata alam di waduk ini menimbulkan dampak lingkungan lingkungan, serta mempunyai risiko bencana bagi wisatawan. Penelitian ini bertujuan untuk mengetahui potensi Waduk Sermo sebagai obyek wisata alam dan secara umum menganalisis dampak lingkungan serta risiko bencana yang ditimbulkan dari kegiatan pariwisata. Penelitian dilakukan dengan survei lapangan, melakukan observasi serta melakukan wawancara dengan mesyarakat setempat. Sampel air waduk diambil untuk mengetahui parameter fisik dan kimia dan dievaluasi dengan persyaratan air untuk pariwisata. Analisis data dilakukan dengan deskriptif kualitatif dan kuantitatif menggunakan tabel dan gambar hasil olahan data. Penelitian ini menunjukkan bahwa Waduk Sermo mempunyai potensi yang bagus untuk pariwisata, tetapi karena
\end{abstract}


fasilitas pendukungnya masih belum memadai, maka kunjungan wisatawan masih belum optimal. Dampak lingkungan yang ditimbulkan oleh kegiatan wisata telah terjadi. Dampak positif yang timbul adalah terbukanya peluang usaha dan peningkatan pendapatan, sedangkan dampak negatif berupa pencemaran oleh sampah dan menurunnya kualitas air. Risiko bencana dapat terjadi berupa kecelakaan aktivitas di dalam perairan waduk yang dipertimbangkan dalam pengembangan Waduk Sermo untuk pariwisata.

Kata kunci: Waduk Sermo, Pariwisata, Dampak lingkungan, Risiko bencana, Pengembangan

\section{PENGANTAR}

Waduk Sermo merupakan satu-satunya waduk (reservoir) yang terdapat di Daerah Istimewa Yogyakarta yang berfungsi sebagai waduk multiguna dengan tujuan sebagai berikut: (a) untuk suplesi Daerah Irigasi Sistem Kalibawang dengan areal 7. $152 \mathrm{Ha}$; (b) menghindari banjir pada musim hujan di daerah-daerah yang sebagian disebabkan oleh banjir Kali Serang dan anak sungai Kali Ngrancah; (c) untuk pengembangan perikanan; (d) sebagai obyek pariwisata; e) sebagai sarana pengembangan olah raga air; f) sebagai sumber air baku air minum Kabupaten Kulon Progo. Sejak dibangun, waduk ini banyak menarik para wisatawan, terutama wisatawan lokal. Pengunjung banyak berdatangan, terutama pada hari-hari libur. Perkembangan jumlah pengunjung berfluktuasi, sehingga ketidakajegan jumlah pengunjung perlu mendapat perhatian agar obyek wisata tersebut tetap bertahan, dan bahkan berkembang.

Secara administrasi, Waduk Sermo terletak $\pm 30 \mathrm{Km}$ sebelah Barat Kota Yogyakarta, tepatnya di Desa Hargowilis, Kecamatan Kokap, Kabupaten Kulon Progo. Letak geografis waduk ini berada pada koordinat 7 50' LS dan110 10' BT (Gambar1). Elevasi daerah penelitian ini berada pada ketinggian 141 mdpal. Daerah sekitar waduk merupakan bagian dari Perbukitan Menoreh. Waduk dikelilingi oleh perbukitan denudasional yang terkikis lemah hingga sedang. Waduk ini airnya dipasok dari beberapa sungai, sedang outlet waduk merupakan bagian dari dataran koluvial.
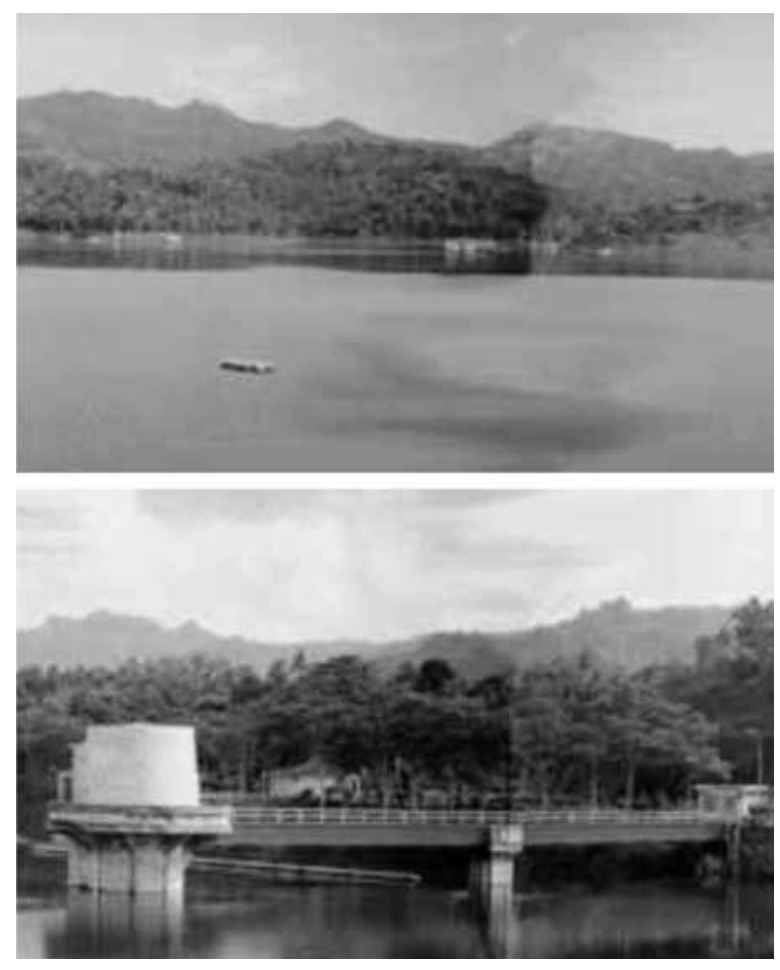

Gambar 1

Obyek Wisata Waduk Sermo

Di desa Hargowilis dimana waduk tersebut berada, dalam kurun waktu 4 tahun (2005-2009) terdapat sekitar 7 ribu jiwa. Akan tetapi, pada tahun 2010 hanya sekitar 5 ribu jiwa. Hal ini juga dipengaruhi oleh peningkatan minat transmigrasi oleh penduduk di sekitar Waduk Sermo. Sebagian besar penduduk Desa Hargowilis berusia dewasa (BPS, 2010) yang bekerja di sektor pertanian. Pertanian di desa ini dapat dibedakan menjadi dua, yaitu pertanian lahan basah dan pertanian lahan kering. Pertanian lahan basah meliputi sawah irigasi dan sawah tadah hujan, sedang pertanian lahan kering berupa kebun dan ladang. Seiring berjalannya waktu, pekerjaan penduduk bergeser dari sektor pertanian ke sektor perdagangan dan jasa. Beberapa Kepala Keluarga (KK) juga memilih sektor pertambangan (Tabel 1). 


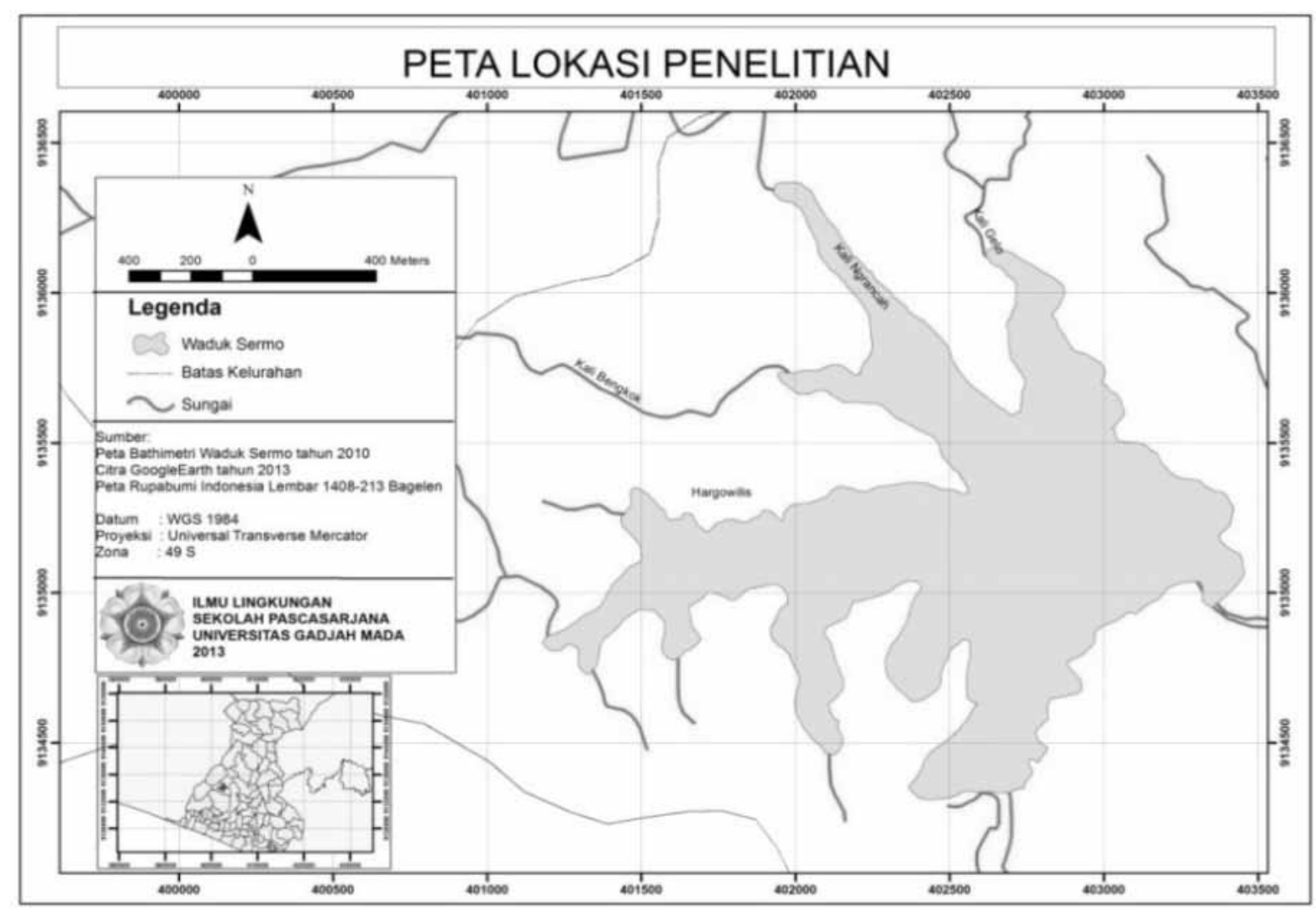

Gambar2

Peta Lokasi Penelitian

Tabel1

Jumlah Penduduk Desa Hargowilis (Jiwa)

\begin{tabular}{l|l|l|l}
\hline \multirow{2}{*}{ Tahun } & \multicolumn{2}{|c|}{ Jumlah penduduk } & \multirow{2}{*}{ Total } \\
\cline { 2 - 3 } & Laki-laki & Perempuan & \\
\hline 2005 & 3519 & 3726 & 7245 \\
\hline 2006 & 5104 & 2205 & 7309 \\
\hline 2007 & 3598 & 3773 & 7371 \\
\hline 2008 & 3497 & 3531 & 7028 \\
\hline 2009 & 3540 & 3590 & 7130 \\
\hline 2010 & 2755 & 2859 & 5614 \\
\hline 2011 & 2764 & 2868 & 5632 \\
\hline
\end{tabular}

Sumber : BPS, $2005-2011$

Waduk Sermo hanya satu-satunya lokasi wisata yang ada di Desa Hargowilis yang disebabkan oleh kurangnya atraksi yang menarik di daerah tersebut untuk mendukung kegiatan pariwisata. Saat ini di Desa Hargowilis terdapat perkumpulan kesenian dengan berbagai atraksi, tetapi perkumpulan ini kurang berkembang. Terdapat 9 perkumpulan kesenian Jathilan, 1 kesenian Icling dan 5 komunitas kesenian Kethoprak.

Seharusnya, waduk Sermo merupakan satu-satunya waduk yang berada di Daerah Istimewa Yogyakarta (DIY), akan merupakan obyek wisata yang banyak dikunjungi oleh wisatawan di daerah ini. Ternyata kunjungan wisata masih belum seperti yang diharapkan. Penelitian ini bertujuan untuk mempelajari potensi wisata Waduk Sermo, dampak lingkungan yang terjadi, dan risiko bencana yang ada serta kemungkinan pengembangannya.

Banyak obyek wisata alam yang berpotensi untuk dikembangkan di suatu wilayah untuk peningkatan kesejahteran masyarakat. Sumarwoto (2003) telah menge- 
mukakan potensi wisata yang dimiliki Daerah Istimewa Yogyakarta yang dapat dikembangkan. Pengembangan potensi wisata yang disebut dengan ekowisata merupakan salah satu program Pemerintah Provinsi Daerah Istimewa Yogyakarta, yang dituangkan dalam Agenda 21 Pembangunan Pariwisata Berkelanjutan Daerah Istimewa Yogyakarta. Pembangunan pariwisata bukan tidak mempunyai dampak sampingan yang tidak menyenangkan. Sumarwoto (2003) menyebutkan bahwa pengembangan pariwisata mempunyai dampak berupa kerusakan lingkungan hidup, penggunaan narkoba dan penjaja seks komersial. Kerusakan lingkungan sering disebabkan oleh eksploitasi yang berlebihan, penggunaan tak terkendali dan perencanaan obyek-obyek pariwisata yang salah.

Sumberdaya alam yang berupa danau juga dapat diangkat menjadi daya tarik wisata yang dapat diangkat untuk mengangkat tingkat perekonomian masyarakat lokal, walaupun peningkatan kesejahteraan masyarakat bukan semata-mata bersumber dari pariwisata. Penelitian Wantasen (2009) dalam disertasinya menyinggung bagaimana Danau Tondano mempunyai daya tarik untuk pariwisata, di samping juga dimanfaatkan untuk kepentingan lainnya. Di sisi lain, kegiatan pariwisata juga dapat memberikan dampak negatif pada perairan danau.

Daerah Istimewa Yogyakarta tidak memiliki danau, tetapi mempunyai waduk Sermo yang terletak di Kabupaten Kulonprogo, satu-satunya reservoir yang terdapat di daerah ini. Danau yang lain memang ada di daerah Kabupaten Gunungkidul yang merupakan danau karst, tetapi tidak seluas Waduk Sermo. Oleh karena itu, satu-satunya reservoir ini juga merupakan andalan pariwisata di Kabupaten Kulonprogo, selain juga digunakan untuk perikanan, pertanian, pengendalian banjir, dan juga bahan baku air minum serta pembangkit tenaga listrik. Ancaman terbesar dari Waduk dan Danau dari berbagai kegiatan adalah sedimentasi dan eutrofikasi. Penurunan kualitas air yang disebabkan oleh kegiatan perikanan dan pariwisata akan mengancam daya dukung lingkungan Waduk Sermo. Piranti (2011) mengungkapkan hal ini juga dalam disertasinya yang mengambil penelitian di Waduk Sudirman Banjarnegara bahwa waduk tersebut terancam pendangkalan dan sedimentasi dari daerah hulunya yaitu Dataran Tinggi Dieng.

\section{Dampak Lingkungan dan Risiko Bencana}

Setiap kegiatan pembangunan tentu dimaksudkan dapat memberikan dampak positif berupa peningkatan kesejahteraan masyarakat. Akan tetapi, dampak lingkungan yang sering timbul adalah dampak lingkungan negatif. Pengembangan obyek pariwisata alam dapat mengancam kelestarian sumberdaya alam yang ditawarkan sebagai obyek wisata. Dampak lingkungan yang timbul akibat pembangunan sarana dan sarana pendukung obyek wisata dapat terjadi, karena prinsipnya akan mengubah penggunaan lahan. Di samping itu, perilaku wisatawan dapat juga memberikan dampak negatif pada lingkungan sekitarnya, baik lingkungan fisik, biotik maupun lingkungan sosial ekonomi. Otto Sumarwoto (2003) menjelaskan bahwa dan perilaku wisatawan yang pada umumnya kaum muda dapat melakukan vandalisme (corat-coret) di obyekobyek wisata alam, sehingga pemandangan tidak lagi bagus. Kunjungan wisatawan dapat meningkatkan perekonomian masyarakat setempat, tetapi dapat juga budaya asing yang tidak sesuai dengan budaya asli masyarakat dapat mengikis budaya dan kearifan lokal, walaupun hal ini tidak diinginkan. Nilai kegotongroyongan dapat berkurang dan bahkan luntur akibat semuanya sudah dinilai dengan uang.

Pengembangan obyek wisata alam dapat juga mempunyai risiko terhadap terjadinya bencana alam. Seringkali obyekobyek wisata alam terletak pada daerah 
yang rentan terhadap bencana alam. Hal tersebut dapat dikaji dari berbagai macam obyek wisata alam yang terletak di daerah gunungapi Merapi. Erupsi Merapi tahun 2010 telah memberikan gambaran yang sangat jelas bagaimana obyek wisata alam dapat hancur karena erupsi Merapi pada tahun tersebut. Pengembangan wisata di daerah karst berupa bukan luput dari bencana. Gua Seropan telah memakan korban tiga pecinta alam meninggal karena banjir yang terjadi di dalamnya. Beberapa waktu sebelumnya, di Goa Sriti beberapa wisatawan terjebak selama 8 jam di dalam goa karena banjir, dan baru dapat terselamatkan dengan bantuan tim SAR. Ketika obyek wisata goa dibuka, haruslah dipahami risiko bencana yang mungkin menimpa wisatawan yang seharusnya tidak boleh terjadi. Oleh karena itu, pendidikan tentang wisata goa karst diperlukan (Sunkar dkk. , 2013). Wisata danau juga harus diwaspadai karena mungkin juga bencana dapat timbul pada wisatawan ketika mereka sedang melakukan aktivitas wisata. Aktivitas wisata dengan menggunakan perahu dan mungkin juga berenang, tidak luput dari risiko untuk tenggelam. Untuk itu, persiapan untuk mengantisipasi kejadian ini juga harus dilakukan dengan sebaikbaiknya. Kecelakaan di mana pun dapat terjadi, sehingga hal ini harus dipersiapkan sedini mungkin apabila suatu obyek wisata alam akan dikembangkan.

Penelitian ini dilakukan dengan cara survei lapangan. Observasi di lapangan, dilakukan yang lebih difokuskan di perairan waduk, dilanjutkan dengan melakukan pengukuran kondisi fisik lingkungan waduk, pengambilan sampel air waduk. Wawancara di lapangan dengan mengambil para pemangku kepentingan dalam pariwisata.
Sampel air waduk diambil dan dianalisis di laboratorium dan dilihat dari kesesuaian kualitas air waduk bagi peruntukan kegiatan pariwisata, berdasarkan atas parameter fisik dan kimia. Kualitas air yang dipersyaratkan untuk kegiatan pariwisata mengacu baku mutu kelas II PP 82 Tahun 2001. Sampel air diambil sebanyak12yang terdiri dari 8 sampel di dalam waduk, sedangkan 4 sampel lainnya pada inlet sungai yang masuk ke Waduk Sermo yaitu Kali Lurung, Kali Bengkok, Kali Ngrancah, dan Kali Gelo (Gambar 3). Parameter fisik air yang di analisis meliputi suhu, DHL (Daya hantar Listrik), Kekeruhan, TDS (Total Dissolved Solids), dan TSS (Total Suspended Solids). Parameter kimia air yang dianalisis meliputi $\mathrm{pH}$, Nitrat $\left(\mathrm{NO}_{3}^{-}\right)$, Nitrit $\left(\mathrm{NO}_{2}^{-}\right)$, Amoniak $\left(\mathrm{NH}_{3}^{-} \mathrm{N}\right)$, Phosphat $\left(\mathrm{PO}_{4}^{-} \mathrm{P}\right)$, Besi Total (Fe), DO (Dissolved Oxygen), BOD (Biochemical Oxygen Demand), COD (Chemical Oxygen Demand), Deterjen sebagai MBAS, dan minyak lemak.

Responden dalam wawancara merupakan warga asli Desa Hargowilis. Sebanyak 30 orang responden diambil, terdiri dari lakilaki $60 \%$ dan perempuan sebanyak $40 \%$. Usia responden bervariasi $<20$ tahun hingga $>35$ tahun. Sebagian besar responden berusia $>$ 35 tahun $(63,3 \%)$, sedangkan paling sedikit berusia $<20$ tahun sebanyak 3,3\%. Responden yang berusia 20-24 tahun sebanyak 10\%, usia 25-29 tahun sebanyak $10 \%$ dan usia 30-34 tahun sebesar 13,3\%. Data sekunder dalam penelitian ini dikumpulkan dari instansi terkait, yaitu dari Dinas Pariwisata Kabupaten Kulonprogo untuk hal-hal yang terkait dengan pariwisata, dan dari Balai Besar Waduk Sermo untuk hal-hal yang terkait dengan data teknis Waduk Sermo. Analisis data dilakukan dengan deskriptif kuantitatif maupun kualitatif. 


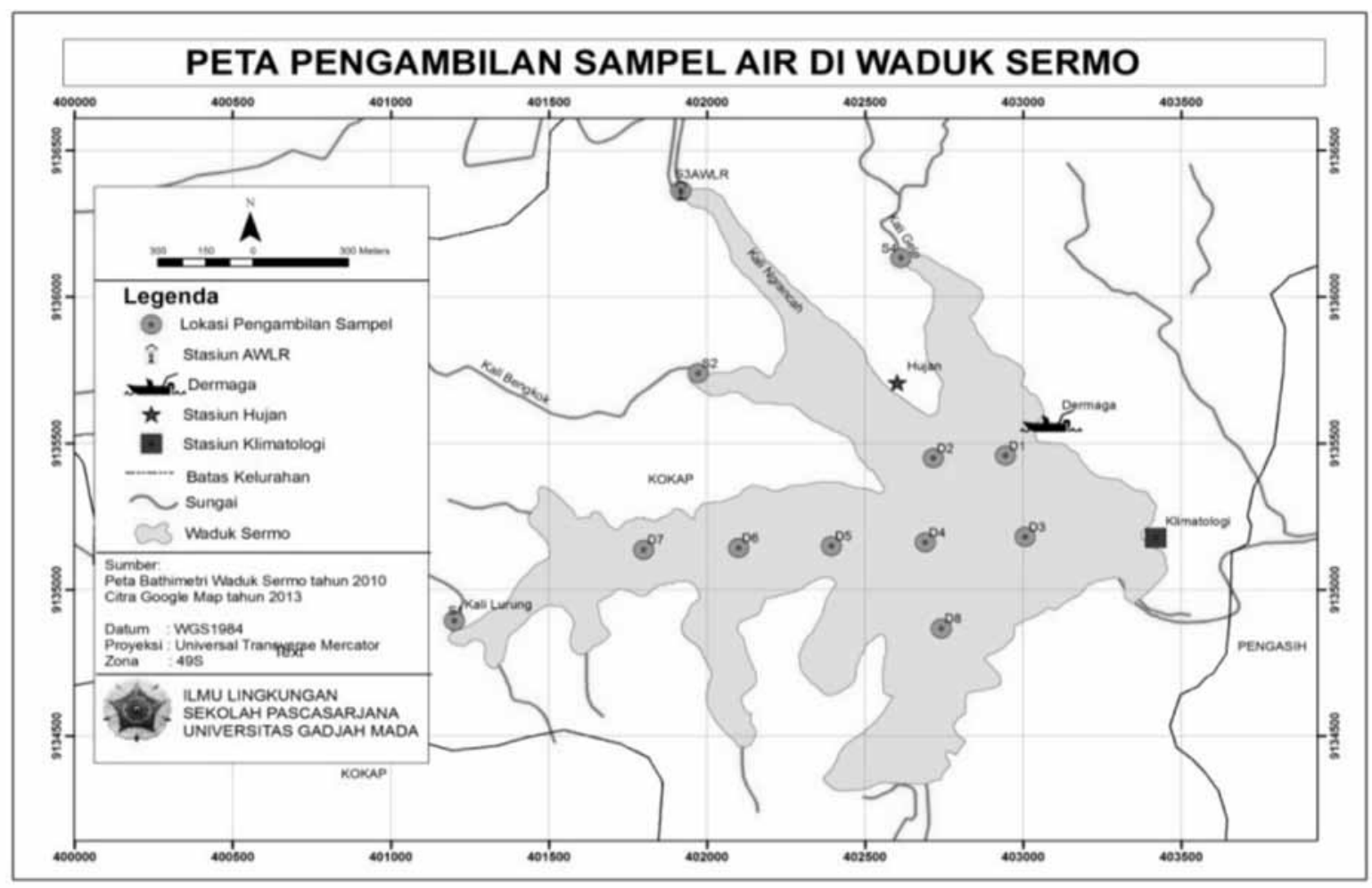

Gambar 3

Lokasi Pengambilan Sampel Air di Waduk Sermo

\section{PEMBAHASAN}

\section{Potensi Waduk Sermo untuk} Pengembangan Kegiatan Wisata Alam

\section{Kuantitas Air Waduk Sermo}

Waduk Sermo mempunyai spillway sepanjang 190 meter dan tinggi puncak 58,60 meter. Waduk ini mampu menampung aliran air dari Kali Ngrancah dengan kapasitas tampungan 25 juta $\mathrm{m}^{3}$ dengan tampungan mati 3,1 juta $\mathrm{m}^{3}$ dan tampungan bersih 21,9 juta $\mathrm{m}^{3}$. Tabel 2. menunjukkan karakteristik teknis Waduk Sermo.

Tabel2

Karak teristik Teknis Waduk Sermo

\begin{tabular}{l|l|l}
\hline No. & \multicolumn{1}{|c}{ Karakteristik } & \multicolumn{1}{c}{ Ket } \\
\hline 1. & Luas DAS Ngrancah & $21 \mathrm{~km}^{2}$ \\
\hline 2. & Tinggi Waduk & 52,6 meter \\
\hline
\end{tabular}

\begin{tabular}{l|l|l}
\hline No. & \multicolumn{1}{|c|}{ Karakteristik } & \multicolumn{1}{c}{ Ket } \\
\hline 3. & Panjang puncak waduk & 190 meter \\
\hline 4. & Luas Waduk & $1,4 \mathrm{~km}^{2}$ \\
\hline 5. & Volume Air Waduk & 25 juta $\mathrm{m}^{3}$ \\
\hline 6. & Tipe waduk & $\begin{array}{l}\text { Urugan batu } \\
\text { dengan inti } \\
\text { kedap air }\end{array}$ \\
\hline 7. & $\begin{array}{l}\text { Luas Genangan } \\
\text { Maksimum }\end{array}$ & ha \\
\hline 8. & $\begin{array}{l}\text { Luas Daerah } \\
\text { Tangkapan Air Hujan }\end{array}$ & $21 \mathrm{~km}^{2}$ \\
\hline
\end{tabular}

Sumber : Balai Besar Sermo, 2013.

Hasil monitoring waduk Tahun 20082012 (Tabel 3) menunjukkan bahwa volume air yang keluar ini juga termasuk air yang telah dimanfaatkan penduduk sebagai air irigasi dan air baku yang dikelola oleh PDAM. 
Tabel 3

Imbangan Air Waduk Sermo

\begin{tabular}{|c|c|c|c|c|c|c|}
\hline \multirow[b]{2}{*}{ Tahun } & \multirow{2}{*}{$\begin{array}{c}\text { Volume } \\
\text { Masuk (Juta } \\
\mathbf{m}^{3} \text { ) }\end{array}$} & \multirow{2}{*}{$\begin{array}{c}\text { Volume } \\
\text { Keluar (Juta } \\
\left.\mathbf{m}^{3}\right)\end{array}$} & \multicolumn{3}{|c|}{ Volume Keluar Melalui } & \multirow[b]{2}{*}{ Selisih } \\
\hline & & & $\begin{array}{l}\text { Spillway } \\
\text { (Juta m }^{3} \text { ) }\end{array}$ & $\underset{\mathrm{Q}_{\mathrm{PDAM}}}{\mathrm{Juta} \mathrm{m}^{3} \text { ) }}$ & $\begin{array}{c}\text { Terowongan } \\
\left(\text { Juta }^{3} \text { ) }\right.\end{array}$ & \\
\hline 2008 & 39,87 & 36,26 & 16,38 & 0,95 & 18,93 & 3,61 \\
\hline 2009 & 24,26 & 31,04 & 2,52 & 0,95 & 27,58 & 6,78 \\
\hline 2010 & 52,29 & 44,71 & 19,02 & 0,95 & 24,69 & 7,58 \\
\hline 2011 & 47,32 & 53,28 & 19,34 & 0,94 & 32,99 & 5,96 \\
\hline 2012 & 23,52 & 19,16 & 4,11 & 0,95 & 14,10 & 4,36 \\
\hline
\end{tabular}

Sumber : Data Monitoring Waduk Sermo Tahun 2008-2012

\section{Kualitas Air Waduk Sermo}

Pada kegiatan pariwisata di Waduk Sermo, kualitas air mempunyai peran yang sangat penting. Wisata air memerlukan persyaratan tertentu akan kualitas air. Sebaliknya kegiatan pariwisata dapat menimbulkan dampak pada kualitas air. Kegiatan wisata, seperti berperahu, belanja, rumah makan di sekitar waduk dapat menghasilkan limbah yang akan mempengaruhi kualitas air waduk. Pada uraian ini kualitas air dikaitkan dengan persyaratan air untuk wisata menurut Baku Mutu Air Kelas 2 PP No. 82 tahun 2001 tentang Pengendalian pencemaran Air.

\section{Kualitas Fisik}

Kualitas fisik air yang dikaji meliputi suhu, DHL (Daya hantar Listrik), dan TSS (Total Suspended Solids). TDS (Total Dissolved Solids) dan kekeruhan, Pengukuran suhu dan DHL dilakungan langsung di lapangan, sedangkan yang lain dianalisis di laboratorium.

a) Daya Hantar Listrik (DHL). Daya Hantar Listrik (DHL) adalah ukuran kemampuan air untuk meneruskan arus listrik. Semakin banyak garam yang terlarut yang dapat terionisasi maka akan semakin tinggi nilai DHL tersebut. Hasil pengukuran DHL di setiap lokasi pengambilan sampel menujukkan nilai 488-611 $\mu \mathrm{mhos} / \mathrm{cm}$. Nilai tersebut tergolong tinggi untuk air permukaan, tetapi masih tergolong air tawar. b) Total Suspended Solid (TSS). TSS terdiri dari lumpur dan pasir halus serta jasadjasad renik terutama disebabkan oleh erosi tanah di sekitarnya yang terbawa ke badan air. Berdasarkan hasil analisis menunjukkan, kadar TSS di Waduk Sermo berkisar antara 1,21-5,50 mg/1. Ambang batas baku mutu kelas II untuk kadar TSS adalah $50 \mathrm{mg} / \mathrm{l}$, sehingga seluruh sampel masih jauh di bawah ambang batas. Kadar TSS tertinggi sampel air ada pada sampel D7 yaitu 5,5 $\mathrm{mg} / 1$. Lokasi sampel ini dekat dengan inlet Kali Lurung, sehingga inlet ini mempunyai pengaruh terhadap kadar TSS di D7 meskipun kadar TSS di S1 $2,18 \mathrm{mg} / 1$.

c) Total Dissolved Solid (TDS). Nilai TDS tidak selalu berkorelasi dengan kadar TSS dan kekeruhan. Kadar TDS di Waduk Sermo berkisar 80-296 mg/1. Kadar tersebut masih di bawah ambang batas baku mutu yaitu $1000 \mathrm{mg} / \mathrm{l}$. Kadar TDS terendah terdapat pada sampel S4 yaitu $296 \mathrm{mg} / \mathrm{l}$, sedangkan tertinggi terdapat pada sampel D1 yaitu $80 \mathrm{mg} / \mathrm{l}$.

d) Kekeruhan. Berdasarkan hasil analisis laboratorium diketahui bahwa nilai kekeruhan di Waduk Sermo berkisar antara 5,5-32,6 NTU. Nilai terendah ada pada sampel D8 dan tertinggi sampel D4. Selain untuk obyek wisata, Waduk Sermo juga dimanfaatkan untuk suplai air minum PDAM. Berdasarkan 
pengamatan lapangan, kondisi air pada saat pengukuran terlihat jernih.

\section{Kualitas Kimia Air}

Parameter kimia air yang dianalisis dalam penelitian ini adalah $\mathrm{pH}$, Nitrat $\left(\mathrm{NO}_{3}^{-}\right)$, Nitrit $\left(\mathrm{NO}_{2}^{-}\right)$, Amoniak $\left(\mathrm{NH}_{3}-\mathrm{N}\right)$, Fosfat $\left(\mathrm{PO}_{4}^{-} \mathrm{P}\right)$, Besi Total (Fe), DO (Dissolved Oxygen), BOD (Biochemical Oxygen Demand), COD (Chemical Oxygen Demand), Deterjen sebagai MBAS dan minyak lemak.

a) Konsentrasi Ion Hidrogen $(\mathrm{pH})$. Hasil pengukuran lapangan menunjukkan bahwa nilai $\mathrm{pH}$ pada titik sampel yang diambil antara 8,60-9,47. Rentang nilai $\mathrm{pH}$ yang ditetapkan dalam baku mutu kelas II menurut PP No. 82 Tahun 2001 adalah 6-9. Berdasarkan ambang batas ini, sampel S1, S2 dan S3 sudah melebihi ambang batas baku mutu, sementara yang lainnya menunjukkan nilai yang mendekati batas atas ambang. Nilai $\mathrm{pH}$ yang tinggi (suasana alkalis) akan berpengaruh terhadap kehidupan biota perairan.

b) Nitrat $\left(\mathrm{NO}_{3}^{-}\right)$.Hasilanalisis laboratorium menunjukkan kadar nitrat sampel air Waduk Sermo sangat rendah yaitu $\leq$ 0,066 mg/1 (limit of detection) kecuali pada sampel D5 sebesar 1,04 mg/l dan S3 sebesar 4,115 mg/l. Kadar tersebut masih di bawah ambang batas yang ditetapkan baku mutu air kelas II yaitu sebesar $10 \mathrm{mg} / \mathrm{l}$.

c) Nitrit $\left(\mathrm{NO}_{2}^{-}\right)$. Sumber nitrit dapat berasal dari limbah industri dan domestik. Nitrit merupakan senyawa yang dapat merugikan bagi kesehatan karena bersifat racun. Berdasarkan hasil analisis laboratorium diketahui bahwa kadar nitrit sampel air Waduk Sermo $\leq$ 0,0009 hingga 1,47 mg/1. Seperti halnya nitrat, kadar nitrit yang terukur pada beberapa sampel air (D2, D7, D8, S1, S3 dan S4) dibatas deteksi alat yaitu $\leq 0,0009 \mathrm{mg} / \mathrm{l})$. Ambang batas kadar nitrit baku mutu air Kelas II sebesar
0,06 mg/l, sehingga semua sampel air Waduk Sermo telah melebihi ambang batas baku mutu yaitu sampel D1, D3, D4, D5, D6 dan S2.

d) Amonia $\left(\mathrm{NH}_{3}^{+} \mathrm{N}\right)$. Sumber antropogenik dapat berasal dari air pembuangan (air seni) atau pembusukan zat-zat organik. Keberadaannya sebagai indikasi adanya pencemaran. Sebagian besar kadar amoniak sampel air berada pada batas deteksi alat yaitu 0,0094 mg/1 kecuali sampel S2 yaitu 0,678 mg/l. Ambang batas kadar nitrit untuk kelas II tidak ditetapkan, namun demikian menurut Sawyer dan Mc Carry (1978) kadar amoniak di perairan tidak boleh melebihi 0,2 mg/l, karena dapat bersifat toksik bagi organisme air.

e) Fosfat $\left(\mathrm{PO}_{4}^{3-}\right)$. Berdasarkan hasil analisis laboratorium, kadar fosfat sampel air Waduk Sermo berkisar antara 0,0620,599 mg/1, yang terendah di D7 dan tertinggi di S4. Ambang batas kadar fosfat baku mutu air kelas II menurut adalah $0,2 \mathrm{mg} / 1$. Mengacu nilai tersebut maka kecuali sampel D7, telah telah melebihi ambang batas. Dimungkinkan tingginya kadar fosfat ini disebabkan oleh dekomposisi bahan organik dan limbah pertanian yang berasal dari kegiatan pertaniah di sekitar waduk.

f) Besi Total (Fe). Besi merupakan unsur utama bagi mahkluk hidup. Besi ditemukan dalam bentuk ferro $\left(\mathrm{Fe}^{2+}\right)$ dan ferri $\left(\mathrm{Fe}^{3+}\right)$. Kadar besi yang terdapat dalam sampel air Waduk Sermo sangat kecil, sehingga nilai yang terukur pada batas deteksi alat yaitu 0,0011 mg/l. Kadar besi tidak dipersyaratkan untuk baku mutu air kelas II.

g) Dissolved Oxygen (DO). Kadar oksigen terlarut pada perairan alami biasanya kurang dari $10 \mathrm{mg} / \mathrm{l}$. Pada perairan danau, oksigen lebih banyak dihasilkan oleh fotosintesis algae yang banyak terdapat pada zona epillimnion, atau oleh tumbuhan air di zona litoral pada 
perairan tergenang dangkal (Effendi, 2003). Hasil analisis menunjukkan bahwa kadar DO sampel air Waduk Sermo antara 6,81-8,12 mg/l. Ambang batas baku mutu adalah $4 \mathrm{mg} / \mathrm{l}$, sehingga kadar DO di Waduk Sermo masih dalam kondisi baik, karena semua sampel menunjukkan nilai di atas ambang batas.

h) Biochemical Oxygen Demand (BOD). Biochemical Oxygen Demand (BOD) merupakan jumlah oksigen yang dibutuhkan oleh mikroba aerob untuk mengoksidasi bahan organik menjadi karbon dioksida dan air. BOD hanya menggambarkan bahan organik yang dapat didekomposisi secara biologis (biodegradable). Bahan organik ini dapat berupa lemak, protein, kanji, glukosa, aldehide, dan ester. Bahan organik merupakan hasil pembusukan tumbuhan dan hewan yang telah mati atau hasil buangan dari limbah domestik dan industri. Peningkatan BOD dapat digunakan sebagai indikator pencemaran yang terjadi, semakin meningkat jumlah kandungan BOD berarti air limbah itu sudah mulai tercemar. Hasil analisis menunjukkan bahwa BOD Waduk Sermo antara 0,7$1,7 \mathrm{mg} / 1$. Nilai terendah pada sampel D4 dan tertinggi pada sampel S2. Nilai ambang batas yang dipersyaratkan baku mutu adalah $3 \mathrm{mg} / \mathrm{l}$. Dengan demikian keseluruhan sampel masih berada di bawah ambang batas baku mutu kelas II.

i) Chemical Oxygen Demand (COD). Nilai COD menunjukkan banyaknya oksigen yang diperlukan untuk mengoksidasi zat organik dan anorganik dalam suatu larutan. Jika bahan organik terlarut merupakan bahan organik tahan terhadap proses penguraian dan sangat lambat mengalami proses penghancuran akan dicirikan oleh nilai COD yang tinggi dan nilai BOD yang rendah. Pengukuran COD ini dimaksudkan untuk mengetahui pencemaran bahan organik. Hasil analisis laboraorium menunjukkan nilai COD Waduk Sermo antara 2,1 hingga 5,1 mg/l. Ambang batas yang ditetapkan untuk baku mutu kelas II adalah $25 \mathrm{mg} / \mathrm{l}$, sehingga keseluruhan sampel air Waduk Sermo masih berada di bawah ambang batas.

j) Deterjen sebagai MBAS . Kadar deterjen di Waduk Sermo bervariasi antara 0,0154 dan 0,3135 mg/1. Ambang batas yang ditetapkan untuk baku mutu kelas II adalah $200 \mu \mathrm{g} / 1$ atau 0,02 mg/1. Dilihat dari nilai ambang tersebut, kadar deterjen air Waduk Sermo telah melebihi ambang batas.

k) Minyak Lemak. Minyak lemak merupakan jenis pencemar yang tergolong bahan organik. Kadar minyak lemak sampel air Waduk Sermo sangat kecil yaitu 0,5 hingga $1 \mathrm{mg} / 1$ pada sampel D4, D7, S4 dan D8. Bahkan beberapa sampel tidak terdeteksi mengandung minyak lemak. Ambang batas yang ditetapkan menurut PP No. 82 Tahun 2001 adalah $1000 \mathrm{mg} / 1$.

Berdasarkan uraian kualitas air Waduk Sermo baik kualitas fisik dan kimia dapat dilihat kesesuaian baku mutu kelas II untuk kegiatan pariwisata menurut PP No. 82 tahun 2001. Dari keseluruhan unsur yang dianalisa, beberapa di antaranya telah melebihi ambang batas baku mutu yang telah ditetapkan, yaitu suhu, $\mathrm{pH}$, nitrit, fosfat, dan deterjen. Tingginya kadar atau nilai unsur yang dianalisis dapat mengindikasikan terjadinya penurunan kualitas air atau pencemaran meskipun tidak keseluruhan unsur. Penurunan kualitas air juga bukan hanya disebabkan oleh kegiatan pariwisata saja. Kegiatan domestik, pertanian dan perikanan juga memberi sumbangan terhadap penurunan kualitas air Waduk Sermo. Penurunan kualitas air di waduk hampir terjadi di waduk 
dan danau di Indonesia, seperti halnya di Danau Tondano yang diteliti oleh Wantasen (2009) dan oleh Piranti (2012) yang meneliti Waduk Sudirman di Jawa Tengah.

\section{Daya Tarik Waduk Sermo Sarana dan Prasarana sebagai Obyek Wisata Alam}

Waduk Sermo memiliki potensi yang tinggi sebagai daerah pengembangan pariwisata didukung oleh suasana yang damai dan alami, pemandangan yang indah, dan penduduk lokal yang ramah. Di DIY seperti dikemukakan oleh Soemarwoto (2003) wisata alam menjadi obyek yang dapat dikembangkan lebih lanjut untuk meningkatkan ekowisata. Waduk Sermo sebagai lokasi rekreasi alternatif untuk menikmati waktu bersama keluarga atau teman, sekedar berkeliling menggunakan sepeda motor atau perahu. Aktivitas memancing juga menjadi salah satu daya tarik wisata. Pemancing berasal dari sekitar kawasan waduk dan juga dari luar daerah.

Beberapa aktivitas berskala lokal maupun nasional juga dilakukan di kawasan waduk. Igir-igir perbukitan dengan lintasan menantang menjadi lokasi Kejuaraan Nasional downhill. Perairan danau juga digunakan sebagai lokasi pemusatan latihan atlet dayung. Jalanan melingkar di tepian danau juga seringkali digunakan untuk lintasan jalan santai atau bersepeda pada hari-hari libur.

Perjalanan menuju Kawasan Wisata Waduk Sermo dari Kota Yogyakarta dapat ditempuh dengan kendaraan pribadi kurang lebih 1,5 jam dan kurang lebih 15 menit dari Kota Wates dengan sarana jalan yang baik. Pada pintu gerbang Kawasan Wisata waduk Sermo terdapat Kawasan Suaka Margasatwa Sermo yang juga merupakan sarana wisata dan laboratorium alam untuk pengamatan burung maupun satwa liar pada kawasan hutan negara. Untuk melindungi catchment area maka dibangun kawasan sabuk hijau (green belt) yang berada dalam batas tanah negara. Kawasan ini juga menambah asri kawasan waduk dengan pemandangan menghijau dan iklim mikro yang sejuk.

Sarana dan prasarana Kawasan Wisata Waduk Sermo meliputi bangunan yang berhubungan dengan tata kelola air, administrasi, dan sarana pendukung wisata. Sarana dan prasarana yang berhubungan dengan tata kelola air meliputi: Bendungan utama, bangunan pelimpah, terowongan pengelak, menara pengambilan, sarana elektrik, sarana mekanik, instrumentasi keamanan bendungan, Instrumentasi hidrologi, dan klimatologi. Untuk mendukung kelancaran administrasi dibangun Bangunan kantor, perumahan, dan mess.

Sarana pendukung wisata meliputi areal parkir, gardu pandang, rest area, masjid, dan beberapa warung makan yang dikelola oleh masyarakat sekitar. Untuk mendukung pelatihan dan training tersedia Wisma Sermo Asri dengan fasilitas 2 meeting rooms, dan 18 kamar. Rest area cukup luas tersedia di bagian timur waduk, dibatasi portal untuk menjaga keamanan bendungan. Dengan dibangunnya portal ini, maka kendaraan yang masuk terbatas, sehingga kendaraan ukuran besar tidak dapat masuk melintasi portal tersebut. Pada sisi utara waduk tersedia area parkir bagi kendaraan pribadi yang juga berfungsi sebagai tempat diadakannya event wisata kesenian dan kuliner pada waktu tertentu.

\section{Layanan Wisatawan}

Kunjungan wisata ke Kabupaten Kulon Progo cenderung naik dari tahun ketahun (Tabel 4). Tempat pariwisata yang banyak diminati berupa wisata pantai. Letak pantai di Kulon Progo relatif lebih mudah dijangkau daripada Kawasan Wisata Waduk Sermo karena letaknya yang berdekatan dengan jalan utama dan kemudahan akses transportasi umum. Waduk sermo sebagai objek wisata mempunyai karakter yang berbeda dengan wisata alam lainnya di Kulon Progo. Waduk sermo lebih menawarkan suasana asri dan kesejukan dibanding 
dengan wisata lain, seperti wisata pantai. Dengan kondisi seperti ini, dimungkinkan hanya kelompok wisatawan tertentu yang menyukai Waduk Sermo.

Tabel 4

Perkembangan Kunjungan Wisata di Kabupaten Kulon Progro

\begin{tabular}{l|l|l|c|c|c|c|c|c|c}
\hline \multirow{2}{*}{ NO } & OBYEK & \multicolumn{7}{|c}{ PERKEMBANGAN KUNJUNGAN WISATA PER TAHUN } \\
\cline { 3 - 10 } & WISATA & $\mathbf{2 0 0 5}$ & $\mathbf{2 0 0 6}$ & $\mathbf{2 0 0 7}$ & $\mathbf{2 0 0 8}$ & $\mathbf{2 0 0 9}$ & $\mathbf{2 0 1 0}$ & $\mathbf{2 0 1 1}$ & $\mathbf{2 0 1 2}$ \\
\hline 1 & $\begin{array}{l}\text { Pantai } \\
\text { Glagah }\end{array}$ & 110.504 & 99.908 & 189.195 & 169.587 & 98.505 & 249.856 & 262.312 & 278.805 \\
\hline 2 & $\begin{array}{l}\text { Pantai } \\
\text { Congot }\end{array}$ & 10.442 & 7.349 & 23.121 & 11.825 & 32.535 & 28.191 & 26.453 & 37.446 \\
\hline 3 & $\begin{array}{l}\text { Pantai } \\
\text { Trisik }\end{array}$ & 41.537 & 25.217 & 51.612 & 34.364 & 29.009 & 29.277 & 27.175 & 23.036 \\
\hline 4 & $\begin{array}{l}\text { Waduk } \\
\text { Sermo }\end{array}$ & 14.424 & 14.199 & 24.083 & 12.049 & 16.331 & 17.920 & 16.816 & 20.554 \\
\hline 5 & $\begin{array}{l}\text { Goa } \\
\text { Kiskendo }\end{array}$ & 3.998 & 3.159 & 3.413 & 3.819 & 5.456 & 6.738 & 3.440 & 6.698 \\
\hline 6 & $\begin{array}{l}\text { Puncak } \\
\text { Suroloyo }\end{array}$ & 2.861 & 2.369 & 3.601 & 10.867 & 10.571 & 9.499 & 9.683 & 10.903 \\
\hline & Jumlah & 183.766 & 152.201 & 295.025 & 242.511 & 292.407 & 341.481 & 345.879 & 377.442 \\
\hline
\end{tabular}

Sumber : Dinas Budparpora Kulon Progo, 2012.

Keindahan alam yang diunggulkan dikemas dengan penataan jogging track, downhill, wisata air, lokasi pemancingan, gardu pandang sehingga pengunjung mempunyai kesan untuk melakukan kunjungan kedua kali dan seterusnya. Kesenian lokal seperti angguk dan incling pada tahun 2012 sebagai agenda rutin pada minggu ke-1 dan ke-3 terbukti meningkatkan kunjungan wisatawan. Kunjungan Wisatawan Waduk Sermo pada tahun 2012 sebanyak 20. 554 pengunjung dan Pendapatan Asli Daerah (PAD) yang disumbangkan $\operatorname{Rp}$ 53.708.000, 00 atau telah memenuhi target pencapaian sebesar 140\% (Dinas Budparpora Kulon Progo, 2012). Desa Wisata Sremo dan Kalibiru yang terletak di sebelah utara Kawasan Waduk Sermo memberikan paket wisata alam dan budaya misalnya outbond, bersepeda, pelatihan pembuatan gula klapa, dan penyediaan makanan tradisional Kulon Progo. Minat wisatawan lokal terhadap desa wisata ini masih rendah tetapi desa wisata ini justru diminati oleh wisatawan manca negara seperti kunjungan dari Australia pada tahun 2012.

\section{Pengaruh Kegiatan Wisata terhadap Peningkatan Kesejahteraan Masyarakat}

Kegiatan pariwisata di Waduk Sermo memberikan dampak positif terhadap kesejahteraan masyarakat di sekitar waduk tersebut. Penduduk yang dahulu sebagai petani dan nelayan, kini dapat membuka warung makan di sekitar Waduk Sermo. Untuk membuka warung di sekitar waduk, ada persyaratan yang harus dipenuhi. Warung yang didirikan ini harus menghadap ke waduk agar mereka tidak membuang sampahnya ke dalam waduk. Pendirian bangunan tidak boleh berada di area sabuk hijau. Dengan membuka warung ini akan meningkatkan pendapatan penduduk. Selain membuka warung makan, kegiatan wisata di Waduk Sermo juga membuka lapangan kerja baru untuk masyarakat, ada yang menjadi petugas retribusi, menjadi petugas parkir, bahkan ada menyewakan perahu wisata. Tiap wisatawan yang ingin menikmati keindahan waduk dengan menggunakan perahu wisata cukup membayar Rp 6. 000,00 (Enam Ribu Rupiah). 


\section{SUDARMADJI DAN WIDYASTUTI \& DAMPAK DAN KENDALA WISATA WADUK SERMO DARI ASPEK LINGKUNGAN HIDUP DAN RISIKO BENCANA}

Penduduk juga memanfaatkan kegiatan wisata dengan menyediakan jasa homestay dan desa wisata. Beberapa pendudukjuga membuat oleh-oleh khas daerah seperti gula kelapa dan ikan crispy. Di sekitar waduk banyak tumbuh pohon kelapa, nira dari pohon kelapa yang menjadi bahan baku untuk pembuatan gula kelapa, sedangkan bahan untuk membuat ikan crispy berasal dari ikan Red Devil (Amphilophus labiatus) yang merupakan ikan invasif di waduk ini. Red Devil bukan merupakan ikan yang tinggi harga jualnya, ikan ini hanya dihargai Rp $5.000 / \mathrm{kg}$. Dagingnya yang sedikit dan durinya yang tajam membuat ikan ini tidak digemari oleh masyarakat untuk dikonsumsi. Harga jual ikan ini berbeda dengan jenis ikan lain seperti ikan nila, di mana harga jual ikan nila dapat mencapai Rp 26.000/kg. Home industry ini mengolah ikan Red Devil menjadi ikan crispy dan juga abon. Setelah diolah, ikan Red Devil ini dapat memberi keuntungan ekonomi. Ikan Red Devil yang dijadikan ikan crispy dijual seharga Rp 50.000/kg., sedangkan yang diolah menjadi abon dijual seharga $\mathrm{Rp} 70.000 / \mathrm{kg}$. Selain memberikan keuntungan bagi pemilik home industry, pengolahan ikan Red Devil ini juga membuka lapangan kerja baru bagi masyarakat yang bekerja di home industry ini. Produk-produk khas Waduk Sermo ini sering dibeli oleh wisatawan yang datang ke Waduk Sermo.

Untuk menarik wisatawan agar berkunjung ke Waduk Sermo, selain melakukan promosi mengenai keindahan waduk ini, juga diadakan atraksi budaya yang rutin dilakukan sebulan 2 kali di minggu I dan III. Atraksi budaya akan menarik lebih banyak wisatawan untuk berkunjung Semakin banyak wisatawan yang datang, semakin besar pula keuntungan yang diperoleh oleh penduduk, sehingga kegiatan wisata di Waduk Sermo ikut meningkatkan kesejahteraan masyarakat.

\section{Dampak Lingkungan dan Risiko Bencana Pengembangan Wisata}

Waduk Sermo sejak awal pembangunan telah memberi dampak terhadap lingkungan sekitarnya. Perubahan hidrologi, iklim mikro, dan ekosistem merupakan perubahanperubahan yang jelas. Dampak lingkungan akibat aktivitas pariwisata di Waduk Sermo dapat dibagi menjadi dampak positif dan negatif. Berdasarkan pengamatan, terdapat satu dampak lingkungan yang menonjol untuk masing-masing kategori.

\section{Dampak Lingkungan Sampah}

Peningkatan jumlah kunjungan wisatawan cenderung meningkatkan volume sampah. Hal tersebut tidak dapat dilihat sekedar dari perspektif terbatasnya fasilitas fisik, tetapi permasalah kesadaran masingmasing individu dan bahkan budaya. Keadaan yang sering dijumpai di lokasi-lokasi wisata adalah buruknya infrastruktur dan pengelolaan sampah yang diperparah budaya masyarakat yang "kurang peduli" dan "kurang bertanggung jawab" terhadap sampah. Hal yang sama terjadi di Waduk Sermo.

Berdasarkan pengamatan secara kualitatif terhadap kondisi sampah di kawasan Waduk Sermo, terdapat dua "zona" distribusi sampah. Konsentrasi sampah mengikuti karakteristik tempat dan fasilitas yang ada. Lokasi yang berdekatan dengan toko penjual makanan, minuman, dan rokok pada umumnya dijumpai banyak sampah. Lokasi yang menyediakan tempat peristirahatan (gazebo) atau lahan parkir memadai juga umumnya menjadi tempat konsentrasi sampah. Hal yang sama juga berlaku pada lokasi memancing.

Area pertama merupakan area dengan kepadatan wisatawan tinggi. Pada area tersebut dapat dijumpai banyak bangunan warung milik warga yang menjual berbagai jenis makanan, selain area parkir yang cukup luas. Jenis sampah yang dijumpai kebanyakan berupa wadah sisa makanan atau minuman dan bungkus rokok yang dapat berupa kertas, plastik, kaleng, dan alumunium foil baik yang terkumpul pada beberapa tempat 
sampah maupun berserakan sampai ke pinggir danau. Masalah sampah pada area ini cukup mengganggu pemandangan.

Area kedua sampah tidak sebanyak pada area pertama. Sampah pada area ini pada umumnya dibawa oleh pemancing. Area kedua ini merupakan lokasi memancing favorit karena memiliki pantai yang berkelok-kelok, air yang relatif dangkal, dan dekat dengan inlet sungai sehingga memiliki produktivitas perairan yang tinggi. Jenis sampah yang ditemukan bersumber dari bekal yang dibawa oleh pemancing seperti wadah plastik minuman, bungkus rokok, dan plastik pembungkus makanan kecil.

\section{Invasive spesies}

Awal mula ikan Red Devil masuk ke Indonesia untuk dijadikan ikan hias. Akan tetapi, ternyata ikan ini memiliki kemampuan berkembangbiak yang tinggi sehingga perkembangbiakannya menjadi tidak terkendali. Red Devil betina mampu bertelur sebanyak 600-700 telur.

Red Devil di Waduk Sermo menimbulkan keresahan bagi nelayan dikarenakan ikan ini memangsa ikan yang bernilai ekonomis tinggi seperti ikan nila. Mereka memangsa telur dan anakan dari ikan nila yang masih kecil, menyebabkan ikan nila di Waduk Sermo sulit berkembang. Dampaknya adalah semakin menurunnya populasi ikan nila di waduk ini. Dengan menurunnya jenis ikan komersial di Waduk Sermo, maka pendapatan nelayan juga menjadi menurun.

\section{Perubahan Sosial Kemasyarakatan}

Perubahan sosial kemasyarakatan dapat dilihat dari tiga sisi, yaitu sejarah, sosial ekonomi, dan perilaku. Dari aspek sejarah, perubahan paling tampak pada distorsi nama lokasi yang pada awalnya adalah "Sremo" menjadi “Sermo". Sremo memiliki arti sejarah karena merupakan nama pengikut Pangeran Diponegoro yang pertama kali membangun settlement di area tersebut, Ki Sremo Joyo. Sementara itu Sermo merupakan nama yang "dipopulerkan" pemerintah dalam pembangunan waduk dan promosi wisata, dan tidak memiliki makna spesifik.

Dari aspek sosial ekonomi, pembangunan waduk, pariwisata menyebabkan peningkatan kondisi ekonomi masyarakat, dan diversifikasi jenis pekerjaan. Pada masa lalu, masyarakat Sremo merupakan petani, ketika waduk dibangun masyarakat mulai beralih profesi dengan berkebun, menanam tanaman tahunan, memelihara ternak, dan mencari ikan. Selain itu, dengan aktivitas wisata menyebabkan banyak warga membuka usaha warung, keramba apung, dan menjadi pegawai instansi di sekitar waduk. Pembangunan waduk dan kegiatan wisata juga membuka akses masyarakat terhadap listrik dan air bersih.

Perubahan perilaku juga terjadi di tengah masyarakat sebagai akibat dari pariwisata. Perubahan tersebut, menurut warga, merupakan hal yang terasa di tengah masyarakat, namun sulit untuk dibuktikan. Wisatawan yang datang membawa budaya dan kebiasaan masing-masing. Hal-hal negatif cenderung lebih mudah ditiru oleh masyarakat lokal. Beberapa warga mengeluhkan fenomena yang terjadi seperti berkurangnya respek terhadap orang yang lebih tua, perubahan gaya berpakaian, unggah-ungguh (sopan santun), dan merebaknya remaja yang menggunakan kawasan Waduk Sermo untuk memadu kasih.

\section{Risiko Bencana}

Waduk dikelilingi oleh perbukitan denudasional terkikis lemah hingga sedang yang merupakan bagian dari Perbukitan Menoreh. Kemiringan lereng perbukitan sekitar 25\% hingga $40 \%$. Potensi risiko bencana yang dapat terjadi di sekitar waduk antara lain longsor. Pengunjung dan masyarakat umumnya menyatakan setuju bahwa rumusan arah pengembangan kawasan waduk harus jelas dan sesuai arahan pengembangan tataruang. Sosialisasi perlu dilakukan bagi pengunjung tentang daerah di sekitar waduk yang rawan terjadi bencana alam. Tempat ini seharusnya dilengkapi dengan tanda-tanda peringatan, 
dan larangan untuk daerah yang tergolong rawan bencana. Oyek wisata Waduk Sermo perlu dilengkapi jalur dan daerah evakuasi untuk antisipasi keadaan darurat. Selain risiko bencana alam, risiko bencana karena kesalahan manusia dapat terjadi di sekitar dan di dalam Waduk Sermo. Aktivitas bersepeda menuruni bukit (downhill) mempunyai risiko kecelakaan. Selain itu kegiatan dayung atau wisata air menggunakan perahu juga berisiko.

\section{Pengembangan Waduk Sermo sebagai Wisata Alam}

Waduk Sermo sebagai wisata alam mempunyai kekuatan, kelemahan, peluang maupun ancamannya. Hal ini perlu dipertimbangkan dalam usaha pengembangannya. Kekuatan yang dimiliki oleh Waduk Sermo antara lain:kondisi daerah wisata masih bagus, atraksi kebudayaan cukup rutin dilakukan, sarana/prasarana penunjang sudah ada, lokasi mudah dicapai, dan ada dukungan pemerintah daerah dan masyarakat. Akan tetapi, Waduk Sermo juga mempunyai kelemahan, yaitu kebersihan lingkungan kurang dijaga, promosi masih kurang, transportasi di sekitar waduk masih terbatas, fasilitas (toko menjual barang khas, resto, kuliner, serta rumah ibadah) masih terbatas dan program dan sarana untuk anakanak masih kurang. Untuk pengembangan ke depan Waduk Sermo mempunyai peluang, yaitu tingginya kunjungan wisata ke Yogyakarta dan sekitarnya, obyek wisata waduk dengan kondisi yang masih asri masih jarang, masyarakat mendukung upaya pengembangan Waduk Sermo, Walaupun demikian terdapat beberapa ancaman dalam pengembangan waduk ini, yaitu masuknya investor yang tidak bersahabat, pengelolaan kawasan yang tidak terintegrasi akibat banyaknya instansi yang berwewenang, rusaknya catchment area, pengelolaan sampah yang buruk, dan rusaknya image kawasan wisata oleh tindakan asusila.

Waduk Sermo mempunyai peluang pengembangan Waduk Sermo cukup terbuka, tetapi perlu mengatasi kelemahan yang ada sekaligus memaksimalkan kekuatan yang dimiliki. Beberapa fasilitas yang belum tersedia dengan layak dan terjangkau antara lain toilet dan sanitasi, tempat ibadah, fasilitas bermain anak-anak, restoran, hotel, toko cinderamata, transportasi di dalam kawasan, serta keterbatasan pemandu wisata. Dalam pengembangan ini diperlukan pemberdayaan masyarakat setempat karena keterlibatan masyarakat setempat sangat menentukan keberhasilan pengembangan ini. Banyak penelitian yang menyampaikan pentingnya pemberdayaan masyarakat ini (Soetrisno, 1995, Kuntowijoyo. 1987, Sudarmadji, Slamet Suprayogi, dan Setiadi, 2010).

Pada empat tahun terakhir, jumlah pengunjung dan retribusi meningkat secara signifikan, yang menandakan masih ada potensi dan kesempatan untuk meningkatkan pemasukan dari sektor pariwisata. Kegiatan pariwisata di Waduk Sermo menunjukkan kemajuan dari tahun ke tahun dengan meningkatnya retribusi yang didapat dari tiket masuk (Gambar4), walaupun masih jauh dibawah retribusi dari Pantai Glagah sebagai lokasi wisata favorit di Kulon Progo.

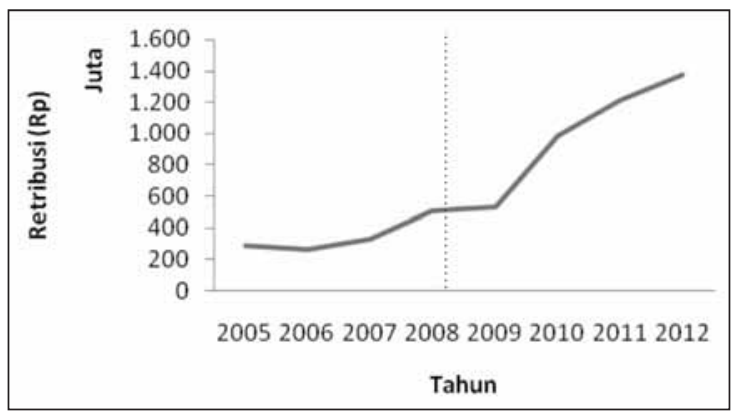

Gambar 4

Total Retribusi Tahunan Sektor Pariwisata (Sumber: Dinas Pariwisata, dan Hasil Analisis, 2013).

Meskipun meningkat secara signifikan, pariwisata pantai masih merupakan kontributor utama dalam penerimaan sektor pariwisata. Tabel 5 menunjukkan bahwa tiga kontributor teratas berasal dari kategori pantai. 
Tabel 5

Kontribusi Berbagai Obyek Wisata di Kabupaten Kulon Progo

\begin{tabular}{l|l|l|l}
\hline No. & \multicolumn{1}{|c|}{ Lokasi } & \multicolumn{1}{|c|}{$\begin{array}{c}\text { Rata-rata Retribusi 2005-2012 } \\
\text { (Rupiah) }\end{array}$} & \multicolumn{1}{|c}{$\begin{array}{c}\text { Rata-rata Jumlah Pengunjung } \\
\text { (Orang) Tahun 2005-2009 }\end{array}$} \\
\hline 1 & Pantai Glagah & $495,642,744$ & 194,834 \\
\hline 2 & Pantai Trisik & $50,358,185$ & 32,653 \\
\hline 3 & Pantai Congot & $49,595,426$ & 22,170 \\
\hline 4 & Waduk Sermo & $28,687,715$ & 17,047 \\
\hline 5 & Puncak Suroloyo & $13,295,506$ & 7,544 \\
\hline 6 & Gua Kiskendo & $8,277,938$ & 4,590 \\
\hline
\end{tabular}

Sumber: Dinas Pariwisata dan Hasil Analisis, 2013.

Pengembangan ekowisata dengan melibatkan masyarakat merupakan pilihan yang baik untuk menjamin keberlanjutan lingkungan sekaligus memberi manfaat yang optimal bagi masyarakat lokal. Kegiatan ekowisata dengan menonjolkan aktivitasaktivitas minat tertentu seperti memancing, dayung, bersepeda, fotografi, perkemahan, dan aktivitas tradisional masyarakat dapat menjadi alternatif yang menarik. Melalui pengembangan tersebut masyarakat memiliki peran dalam pengembangan segala aktivitas atau program yang dapat menarik wisatawan sekaligus menjaga kelestarian lingkungan yang menjadi daya tarik utama. Untuk mencapai hal tersebut dibutuhkan kesadaran dan kerjasama antar pemangku kepentingan, penguatan lembaga masyarakat, konservasi kawasan sekitar waduk, serta tentunya promosi yang baik dan tepat sasaran.

Salah satu kelemahan dari wisata Waduk Sermo adalah kurangnya fasilitas fisik penunjang. Wisatawan memandang Waduk Sermo sebagai tempat yang cukup membosankan karena keterbatasan fasilitas dan aktivitas di kawasan tersebut. Pengunjung yang datang ke Waduk Sermo tidak hanya sekedar datang menikmati suasana damai dan alami, tetapi menikmati makanan berkualitas atau pengalaman unik lainnya. Fasilitas fisik penting untuk menarik wisatawan, meningkatkan waktu tinggal, dan memberi kenyamanan bagi wisatawan.

\section{SIMPULAN}

Beberapa hal yang dapat disimpulkan dari artikel ini sebagai berikut:

Pertama, Waduk Sermo memiliki potensi yang baik sebagai obyek wisata alam, namun masih belum berkembang secara optimal karena fasilitas pendukung pariwisata masih belum memadai.

Kedua, Obyek Wisata Waduk Sermo telah menimbulkan dampak positif terhadap masyarakat dengan berkembangnya berbagai usaha masyarakat sekitarnya yang meningkatkan perekonomian, namun tidak dapat diabaikan timbulnya dampak negatif, berupa sampah dan menurunnya kualitas airperairan waduk, serta timbulnya perilaku negatif dari pengunjung, namun dampak yang timbul juga bukan semata-mata ditimbulkan oleh pariwisata.

Ketiga, Risiko bencana sebagai obyek wisata alam dapat terjadi, mengingat kondisi lingkungan perairan waduk serta morfologi sekitar waduk yang relatif curam.

Keempat, Pengembangan terhadap obyek wisata Waduk Sermo masih mungkin dilakukan dengan mengatasi kelemahan yang dimiliki Waduk Sermo serta memperhatikan peluang yang ada, dibandingkan obyek wisata alam lain di daerah Kabupaten Kulonprogo.

\section{Ucapan Terimakasih}

Tulisan ini merupakan bagian dari penelitian Hibah Bersaing yang dibiayai dari 


\section{SUDARMADJI DAN WIDYASTUTI \& DAMPAK DAN KENDALA WISATA WADUK SERMO \\ DARI ASPEK LINGKUNGAN HIDUP DAN RISIKO BENCANA}

Sekolah Pascasarjana UGM. Pada kesempatan ini, penulis mengucapkan terimakasih kepada Direktur Sekolah Pascasarjana atas fasilitas yang diberikan, serta kepada Tim Peneliti khususnya kepada Saudara Ayudin, Risti Ernawati, dan Nanik Lisawati dari Program Studi Ilmu Lingkungan untuk bantuannya mengumpulkan data di lapangan serta analisis data yang digunakan dalam penyusunan laporan penelitian. Demikian juga terimakasih disampaikan kepada Seluruh Staf Laboratoratorium Hidrologi dan Kualitas Air Fak Geografi yang telah membantu dalam sampling dan analisis air.

\section{DAFTAR PUSTAKA}

Boyd, C. E. 1988. Water Quality in Warmwater Fish Ponds. Fourth Printing. Auburn Univ. Agricultural Experiment Station. Alabama USA.

Fandeli, C. Dan Nurdin, M. 2005. Pengembangan Ekowisata berbasis Konservasi di Taman Nasional.

Effendi, H. 2003. Telaah Kualitas Air bagi Pengelolaan Sumber Daya dan Lingkungan Perairan. Penerbit Kanisius: Yogyakarta.

Kuntowijoyo. 1987. Budaya dan Masyarakat. Yogyakarta: PT. Tiara Wacana Yogya.

Moore, J. W. 1991. Inorganic Contamination of Surface Water. Sporinger Verlag: New York.

Peraturan Pemerintah No. 82 tahun 2001, tentang Pengendalian Pencemaran Air.
Piranti, A.S. 2012. Kajian Kriteria Nutrien sebagai Dasar dalam Penilaian Status Tropik Perairan Waduk Mrica Banjarnegara, Jawa Tengah. Disertasi. Universiitas Gadjah Mada: Yogyakarta.

Randall, A. 1982. Resources Economic, An Economic Approach to Natural Resources and Environment Policy. Illinois.

Rustadi (2008). Konsentrasi Nitrogen dan Fosfor untuk Menaksir Daya Dukung Lingkungan Perairan Budidaya Ikan di Waduk Sermo, Kulonprogo, Daerah Istimewa Yogyakarta. Disertasi. Universitas Gadjah Mada: Yogyakarta.

Sawyer, C. N. , and McCarty, P. L. 1978. Chemistry for Environmental Engineering. McGraw Hill Book Co: New York.

Soetrisno, 1995. Partisipasi dan Pemberdayaan Masyarakat: Sebuah Tinjauan. Laporan Penelitian. Unpublised: Yogyakarta.

Soemarwoto, O. (ed), 2003. Мепијu Jogja Propinsi Ramah Lingkungan. Yayasan Agenda 21 Bandung.

Sudarmadji, Slamet Suprayogi dan Setiadi., 2010. Konservasi Mataair Berbasis Masyarakat di Kabupaten Gunungkidul untuk Mengantisipasi Perubahan Iklim. Laporan Penelitian. Sekolah Pascasarjana UGM: Yogyakarta.

Wantasen, S. 2009. Spasial Ekologi Nitrogen di Danau Tondano, Provinsi Sulawesi Utara. Disertasi. Sekolah Pascasarjana UGM: Yogyakarta. 